\title{
グリーンコンクリートの引張り限界ひずみの定式化に関する研究 FORMULATION OF TENSILE STRAIN AT CRACKING OF GREEN CONCRETE
}

\author{
松藤 泰典*，小山智 幸** \\ Yasunori MATSUFUJI and Tomoyuki KOYAMA
}

\begin{abstract}
The tensile strain at cracking of early age concrete was measured and formulated under the ambient temperature of 15 to $35{ }^{\circ} \mathrm{C}$. The initial brittleness of green concrete was occurred under the influences of rapid reduction of tensile capacity due to the viscosity and increase of it due to the elasticity at early age. The presented formula fitted to the tendency of time-dependent change of experimental value, and coefficients of the formula were shown as the functions of temperature. And further, quantitatively, the formula indicated the minimum value of tensile capacity of green concrete under each temperature ambience.
\end{abstract}

Keywords : Tensile strain at cracking, Green concrete, Plastic cracking, Initial brittleness, Formulation 引張り限界ひずみ，グリーンコンクリート，ブラスチックひび割れ，初期脆性，定式化

\section{1. はじめに}

コンクリートは練混ぜ後暫くの間は大きな変形能力を有してい るが, 水和の進行とともに変形能力を急速に失い，ある時期に極

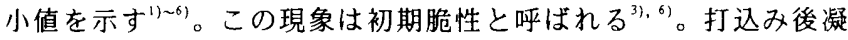
結過程を経て硬化に至る時期のコンクリートはグリーンコンクリ 一トと呼ばれ，内部温度や収縮に起因する引張りにより初期ひび 割れの発生しやすい時期でもある゙ ${ }^{1) ~}$ 。従ってグリーンコンクリー トの伸び能力すなわち引張り限界ひずみの性状を明らかにするこ とは，若材齢におけるひび割れ発生の予測並びに対策を行う上で 極めて重要である。笠井は引張り限界ひずみの特性をコンクリー トの凝結過程と関連づけながら詳細に検討している゙，6)。筆者ら は引張り限界ひずみの極小值が温度が高いほど低くなり，従って 暑中コンクリートでは高温や急激な乾燥によるひび割れが生じゃ

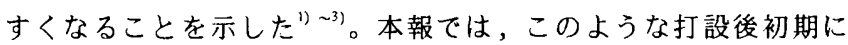
おけるひび割れ発生を定量的に評価するため，この時期における 水和反応の進行に伴う物性変化の特性を考慮しながら, 引張り限 界ひずみの定式化を試みた。なお検討に際しては，上記の温度の 影響を定量化することに主眼をおき，調合や材料は一定としてい る。

* 九州大学大学院人間環境学研究院都市 ·建築学部門 教授・工博

** 九州大学大学院人間環境学研究院都市・建築学部門 助教授・ 工博

\section{2. 引張り限界ひずみの定式化}

図1に，引張り限界ひずみの経時変化の概念図を示す。引張り

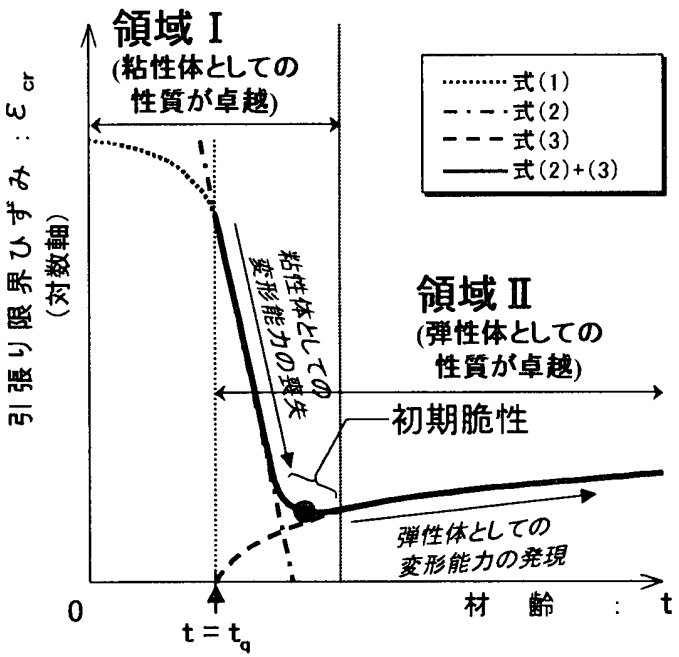

図1 引張り限界ひずみの経時変化の模式図 Studies, Graduate School of Kyushu Univ., Dr. Eng. Assoc. Prof., Dept. of Architecture and Urban Design, Faculty of Human-Environment Studies, Graduate School of Kyushu Univ., Dr. Eng. 
限界ひずみは，打込み直後には大きな值を示すが，水和反応の進

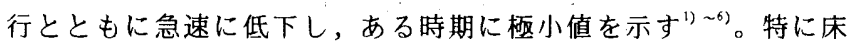
スラブのような薄板部材では，この時期と相前後して表面からの 水分蒸発速度や表層部と中心部の温度差がピークを迎えるためい 4)，プラスチックひび割れの極めて発生しやすい時期となる。

本研究ではこのような引張り限界ひずみの経時変化を, 打込み 後 1 日程度までの極若材歯時におけるコンクリートの物性変化と

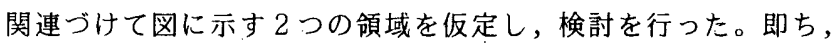
図中，領域 I では粘性体としての性質が卓越して大きな流動性並 びに変形能力を有しているが，ある時点 tq までは徐々に，taから は急速に変形能力を䑤失する。領域 II は弾性体としての性質が卓 越する領域であり，ta以降弾性体としての変形能力を発現して材 齢とともに硬化体へと移行していく。また領域 I と領域 II の重複 部分が存在し，この領域では両者の性質が混在して，ある時点に おいて引張り限界ひずみが全材莑中で最も小さい値を示す現象， 即ち, 初期脆性が生じる。本研究ではこのような仮定のもとに, 上記の現象をできるだけ反映し，はじめに述べた温度の影響を表 すことのできる最も簡便な引張り限界ひずみの算定式を定めるこ とを目的とした。

領域 Iにおける引張り限界ひずみの低下を,既往の実験結果 ${ }^{12}, 3$

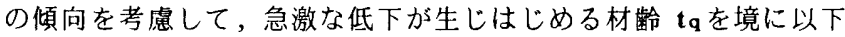
の式(1)および式(2)よって表わされるものと仮定する。式(2)は， コンクリートが長期材齢においても，若材齢時と比較するとその 影響は小さいものの，粘性的性質を有することをも表現している。

$$
\begin{aligned}
& \varepsilon_{\mathrm{cr}(\mathrm{t})}=\varepsilon_{\mathrm{tq}}-\mathbf{a}_{0}\left(\mathbf{t}-\mathbf{t q}_{\mathbf{q}}\right), \quad(0 \leqq \mathbf{t} \leqq \mathbf{t q}) \quad \text { 式(1) } \\
& \varepsilon_{\mathrm{cr}(\mathrm{t})}=\varepsilon_{\mathrm{tq}} \exp \left(-\mathbf{a}_{1}\left(\mathbf{t}-\mathbf{t}_{\mathbf{q}}\right)\right), \quad\left(\mathbf{t} \geqq \mathbf{t}_{\mathbf{q}}\right) \quad \text { 式(2) } \\
& \text { ここに， } \\
& \varepsilon_{\mathrm{cr}}(\mathbf{t}) \quad: \text { 引張り限界ひずみ }\left(\times 10^{-6}\right) \\
& \mathbf{t} \text { : 材齢 (hours) } \\
& \text { tq ：図 } 1 \text { に示す材路 (hours) } \\
& \varepsilon_{\mathrm{tq}} \quad ： \text { 材路 } \mathbf{t q} \text { における引張り限界ひずみ }\left(\times 10^{-5}\right) \\
& \mathbf{a}_{0}, \mathbf{a}_{1} \text { : 係数 }
\end{aligned}
$$

一方，領域IIにおける引張り限界ひずみは，式(3)によって表わ されるものと仮定する。式(3)は，材齢 $\mathrm{tg}$ 以降に弾性体としての 変形能力が発現していく過程を表しており, 式中の $\varepsilon_{\infty} は$, 硬化し たコンクリートの引張り限界ひずみに相当する。

$$
\begin{aligned}
& \varepsilon_{\mathrm{cr}}(\mathbf{t})= \varepsilon_{\infty}\left(1-\exp \left(-\mathbf{a}_{2}(\mathbf{t}-\mathbf{t} \mathbf{q})\right)\right), \quad(\mathbf{t} \geqq \mathbf{t q}) \\
& こ こ に, \text { 式 }(3) \\
& \varepsilon_{\infty}: \text { 材齢 } \mathbf{t}=\infty \text { における引張り限界ひずみ }\left(\times 10^{-6}\right) \\
& \mathbf{a}_{2}: \text { 係数 }
\end{aligned}
$$

本研究では次節に示す実験により若材齢における引張り限界ひ ずみの経時変化を测定し, 上記式(1)〜(3)の妥当性, 並びに式中 の各係数の性質に関して検討を行った。

\section{3. 実験概要}

先に示した式(1)〜 (3)における各定数の值を求めるため, 異な る外気温度下での引張り限界ひずみの経時変化を実測した。

外気温度は $15,20,25,30,35^{\circ} \mathrm{C} の 5$ 水準とした。試験体はコ ンクリートのモルタル部分を想定して, 表 1 に示す水セメント比 $50 \%$ ，セメントと砂の質量比 $1: 2.3$ のモルタルを用いた。使用材 料の諸元を表 2 に示す。先に述べたように本論では引張り限界ひ ずみの経時変化に及ほす温度の影響を定量化することに主眼をお き，調合や材料は一定としている。

引張り限界ひずみの測定に使用した型枠は, 試験体の硬化に伴 う収縮あるいは温度膨張を拘束しないよう軟質のシリコンゴムで 作成し，図 2 に示すように，試験体の幅は中央部分を狭く両端を 広くして, 中央部分にひび割れが生じやすい形状とした。中央部 は幅 $3 \mathrm{~cm}$, 深さ $2 \mathrm{~cm}$, 長さ $6 \mathrm{~cm}$ 程度である。両側の広い部分には 先端を丸めたボルト $(6 \phi)$ を 3 本ずつ配してモルタルと型枠の 付着を向上させた。また型枠の両側には上記のボルトおよび接着 郕を用いてアルミ角パイプを取り付けた。パイプの一方には長ナ ットを固定しており，試験時に載荷フレームを図のように取り付 けて，ボルトを回転することにより試験体を型枠こと引張って引 張りひずみを生じさせた。試験体は打込み直後は主として型枠に より，凝結以降ある程度硬化が進んでからは主としてボルトによ

\begin{tabular}{|c|c|c|c|}
\multicolumn{2}{|c|}{ 表 1} & 試 驗 体 調 合 \\
\hline $\begin{array}{c}\text { 水セメント比 } \\
\text { (\%) }\end{array}$ & \multicolumn{2}{|c|}{ 単 } & 位 量 $\left(\mathrm{kg} / \mathrm{m}^{3}\right)$ \\
\hline 50 & 水 & セメント & 細骨材 \\
\hline 502 & 605 & 1392 \\
\hline
\end{tabular}

\begin{tabular}{|l|c|}
\multicolumn{2}{|c|}{ 表 2 使 用 材 料 } \\
\hline 材 料 & \multicolumn{1}{|c|}{ 諸 } \\
\hline セメント & 普通ポルトランドセメント(比重 3.16) \\
\hline 細骨材 & 玄海産海砂(表乾比重 2.58, 粗粒率 2.72) \\
\hline 練混ぜ水 & 水道水 \\
\hline
\end{tabular}

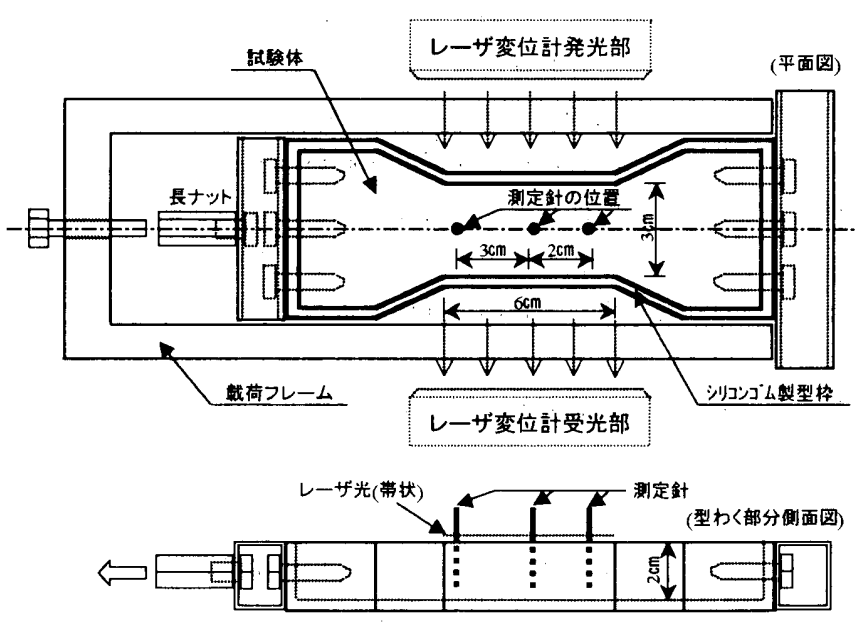

図 2 引張り限界ひずみ测定装置の概要 
り引張りを受けることになる。なお，試験体は試験材龄まで無拘 束の状態とした。また試験体底面および側面はシリコンコム型枠 に接するが，上面は開口しているので，水分蒸発を極力低減する ため打込み直後から試験材齢まで上面をラッピングした。

测定は，図2に示す位置にほほ鉛直に立てた測定針の間隔の載 荷による変動を非接触型レーザー変位計を用いて測定し，載荷前 の測定針間隔で除してひずみを算定した。レーザー変位計の分解 能は $0.1 \mu \mathrm{m}$, 測定針の間隔は約 $20 \sim 30 \mathrm{~mm}$ ありり，ひずみに換 算すると $3.3 \sim 5.0 \times 10^{-6}$ の分解能となる。測定針は 3 本使用し, 一方の測定間煵にひび割れが生じた瞬間他方のひずみが解放され ることを利用してひび割れ発生時期を判断し，そのときのひずみ を引張り限界ひずみとした。また用いた装置は手動のためひずみ

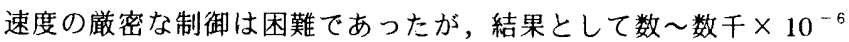
/ sec の籁囲であり，若材齢ほど大きい。なお測定針は試験体に直 接突き刺しており，打込み 30 分後などでは手で押すと傾く状態で あるが, 引張り試験の際には型枠ごと試験体を引張るため，試験 体と一体となって動いていた。また引張り限界ひずみが極小值を 示す時期以降は素手で引き抜くのにかなりの力を要する程の付着 を生じていた。

測定材齢は打込み 30 分後から材齢 24 時間までとした。材齢 12 時間までは原則として 1 時間おきに測定し，引張り限界ひずみの 変動が大きい時期には 30 分間隔とした。また材䊅 12 時間以降は 適宜 $2 \sim 6$ 時間間隔で測定を行った。各材齢において試験体数は 3 体を基本としているが，測定針どうしの間にひび割れが生じな かった場合や測定値のばらつきが大きい場合には，必要に応じて 追加を行った。

\section{4. 結果および考察}

図 3 に，一例として外気温度 $35^{\circ} \mathrm{C}$ の場合の引張りひずみの実験 結果および2。で示した算定式(1)，(2)を実験值に適用した結果 を示す。同図に示すように領域 Iの前半は引張り限界ひずみが材 齢に対して直線関係に，同じく後半は縦軸を対数軸で表した場合 に直線関係になるので，それそれにおいて最小自乗法を適用して 各式の係数の值を定めた。この際，例えば式(2)を適用する場合に

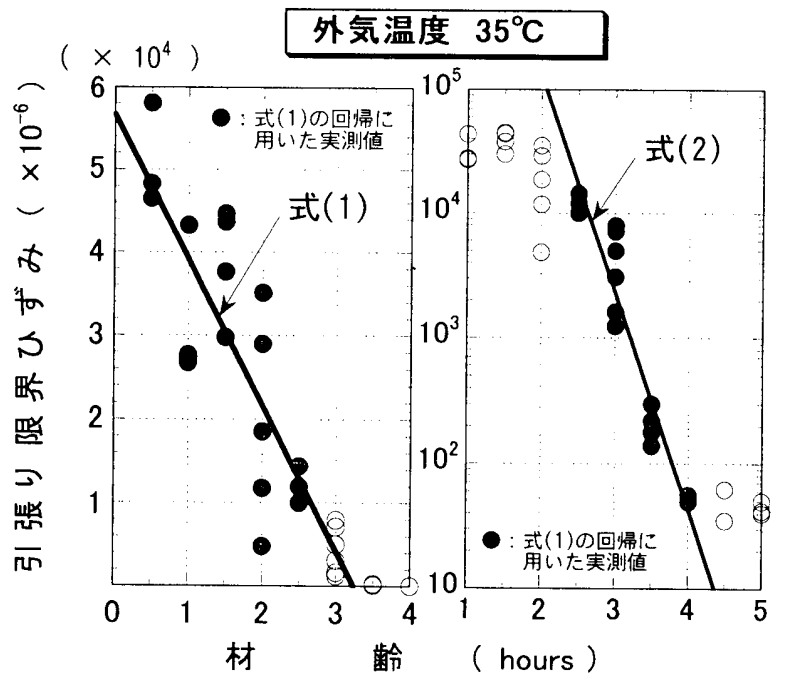

図 3 引張り限界ひずみの経時変化 (外気温度 $35^{\circ} \mathrm{C}$ )
表3 式(1)，(2)中の $\mathrm{tq}_{\mathrm{q}}, \mathrm{a}_{0}, \mathrm{a}_{1}, \varepsilon_{\mathrm{tq}}$

\begin{tabular}{|c|c|c|c|c|c|}
\hline $\begin{array}{c}\text { 外気温度 } \\
\left({ }^{\circ} \mathrm{C}\right)\end{array}$ & $\begin{array}{c}\mathbf{a}_{0} \\
\times 10^{4} \\
\end{array}$ & $\mathbf{a}_{1}$ & $\begin{array}{c}\varepsilon_{\mathrm{tq}} \\
\times 10^{-6}\end{array}$ & $\begin{array}{c}\text { tq } \\
\text { (hours) }\end{array}$ & $\begin{array}{c}\text { 始発持間 } \\
\text { (hours) }\end{array}$ \\
\hline 35 & 1.75 & 3.99 & 10300 & 2.65 & 3.03 \\
\hline 30 & 1. 62 & 2. 92 & 12107 & 3.13 & 3.60 \\
\hline 25 & 1. 27 & 2.63 & $\begin{array}{lllll}1 & 1 & 1 & 13\end{array}$ & 4.05 & 4.07 \\
\hline 20 & 1. 13 & 2.25 & 11397 & 4. 65 & 5.10 \\
\hline 15 & 0.97 & 2. 43 & 8395 & 6.35 & 6.67 \\
\hline
\end{tabular}

は, 前後の明らかに傾向の異なる実湘值を除いて回帰を行った。 このようにして得られた式(1)，式(2)中の係数 $\mathbf{a}_{0}$ ，a19值，お よび両式の交点として求められる材齢 $\mathbf{t q}$ の值を示す。

表 3 から明らかなように ta は外気温度が高くなるほど早い時期 に現れ，図4 に示すように以下の式(4)で近似することができた。 なお近似に際しては，tq と外気温度の関係の傾向から式の形とし $\tau, \mathbf{t}_{\mathbf{q}}=\mathbf{t}_{0} /\left(\mathrm{T}-\mathrm{T}_{0}\right)^{\mathrm{n}}$ を仮定し, 式中の係数や乗数を反復計算 により求めた結果, 乗数 $n=1.49 \fallingdotseq 3 / 2$, および他の係数は下記の 値が得られた。

$$
\begin{aligned}
\mathbf{t q}_{\mathbf{q}}=\mathbf{t}_{0} /\left(\mathrm{T}-\mathrm{T}_{0}\right)^{3 / 2}, \quad(15 \leqq \mathrm{~T} \leqq 35) \\
\text { ここに, } \mathrm{T}: \text { 外気温度 }\left({ }^{\circ} \mathrm{C}\right) \\
\mathrm{T}_{0}=-10.6\left({ }^{\circ} \mathrm{C}\right) \\
\mathbf{t}_{0}=7.94 \times 10^{2}
\end{aligned}
$$

式(4)中, 分母の $\mathrm{T} 0=-10.6\left({ }^{\circ} \mathrm{C}\right)$ は, $\mathrm{T}=-10.6\left({ }^{\circ} \mathrm{C}\right)$ のとき $\mathbf{t q}$ $=\infty$ になることを表し，積算温度算定時に「その温度以下では強 度增進がないと考える基準温度 (datum temperature)」の一般的な值 であるー $10^{\circ} \mathrm{C}^{7}$ にほほ対応している。また係数 $\mathbf{t} \mathrm{o}$ は，本実験の場 合 $7.94 \times 10^{2}$ であるが，セメントなどの使用材料や調合によって変 化すると考えられる。

表 3 中に凝結試験により測定された始発時間を $\mathbf{t q}$ とともに併記 している。弾性体としての変形能力が発現しはじめる材齡を表す tq

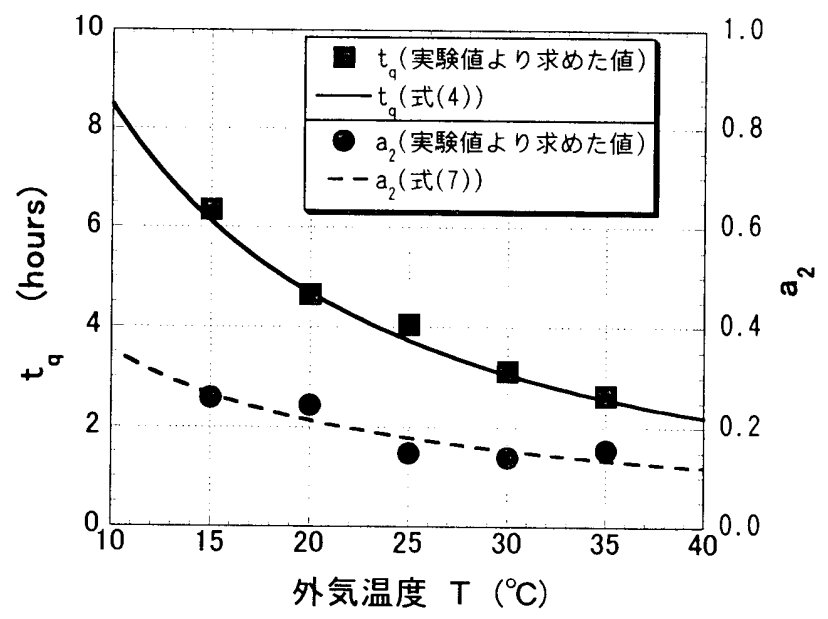

図 $4 \quad t_{q}, a_{2}$ と外気温度の関係 
同様に係数 $\mathrm{a}_{0}$ および $\mathrm{a}_{1}$ は, 因 5 に示すように外気温度 $\mathrm{T}$ の関数 として，以下の式(5)および式(6)で表すことができた。

$$
\begin{aligned}
& a_{0}=a_{00}\left(T-T_{0}\right), \quad(15 \leqq T \leqq 35) \\
& \text { ここに, } \mathrm{T}: \text { 外気温度 }\left({ }^{\circ} \mathrm{C}\right) \\
& \mathrm{T}_{0}=-\mathbf{7 . 8 4}\left({ }^{\circ} \mathrm{C}\right) \\
& \mathrm{a}_{0} 0=4.10 \times 10^{2} \\
& \mathbf{a}_{1}=\mathbf{a}_{10}\left(\mathrm{~T}-\mathrm{T}_{0}\right), \\
& (15 \leqq T \leqq 35) \\
& \text { ここに, } \mathrm{T}: \text { 外気温度 }\left({ }^{\circ} \mathrm{C}\right) \\
& \mathrm{T}_{0}=-12.7\left({ }^{\circ} \mathrm{C}\right) \\
& \text { a } 10=7.57 \times 10^{-2}
\end{aligned}
$$

両式とも温度が高いほど引張り限界ひずみの低下速度が大きく なることを表しており，実测值の傾向とよく対応している。両式 中の $\mathrm{T}$ 。は，值は若干異なるが，先に示した tq T。と同じ意味を有するものと考えられる。

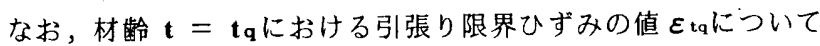
も，若干のばらつきはあるものの，外気温度によらずほぼ一定の 值 $10,000 \times 10^{-6}$ が得られた。

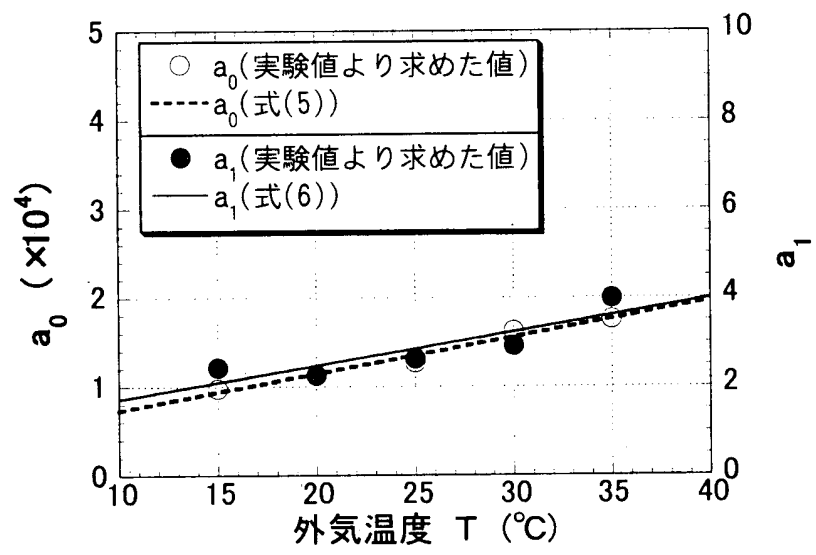

因 5 係数 $\mathbf{a} 0 ， \mathbf{a} 1$ と外気温度の関係

次に，領域IIにおいて式(3)を適用する。適用にあたっては，そ れそれの外気温度において，材齢 $\mathbf{t a}$ 以降の実測值から式(2)の值 を差し引いて得られた値に対して反復計算による式(3)への近似を 行った。この際, 式中の $\mathbf{t q}$ は先の表 3 に示す値を用い, $\mathbf{a} 2$ と $\varepsilon_{\infty}$

表 4 式(3)中の a,$\varepsilon_{\infty}$

\begin{tabular}{|c|c|c|}
\hline $\begin{array}{c}\text { 外気温度 } \\
\left({ }^{\circ} \mathrm{C}\right)\end{array}$ & $\mathbf{a}_{2}$ & $\begin{array}{c}\boldsymbol{\varepsilon}_{\infty} \\
\times 10^{-6}\end{array}$ \\
\hline 35 & 0.16 & 99.6 \\
\hline 30 & 0.14 & 89.0 \\
\hline 25 & 0.15 & 109 \\
\hline 20 & 0.25 & 104 \\
\hline 15 & 0.26 & 127 \\
\hline
\end{tabular}

を算定した。得られた結果を表 4 に示す。

式(2)中の係数 $\mathrm{a} 2$ に関しても，表 4 並びに図 4 中に示すように 外気温度と明瞭な相関が見られ，以下の式(7)で表すことができる。 式中の係数 $\mathbf{a}_{2} 0$ は $\mathrm{t}$ 。と同様，セメントなどの使用材料や調合によ って変化すると考えられる。但し式(7)は，実測値の傾向とは対応 しているものの，領域Iににおける引張り限界ひずみの増大速度が 温度が高いほど小さくなり，化学反応速度論と矛盾する。水和生 成物の状態が高温の場合と低温の場合とで異なることなどが考え られるが，現在合理的な説明を行うに至っていない。

$$
\begin{aligned}
\mathrm{a}_{2}=\mathrm{a}_{20} /\left(\mathrm{T}-\mathrm{T}_{0}\right) \quad, \quad(15 \leqq \mathrm{~T} \leqq 35) \\
\text { ここに, } \mathrm{T}: \text { 外気温度 }\left({ }^{\circ} \mathrm{C}\right) \\
\mathrm{T}_{0}=-\mathbf{5 . 2 7}\left({ }^{\circ} \mathrm{C}\right) \\
\mathrm{a}_{20}=\mathbf{5 . 4 1}
\end{aligned}
$$

また材路 $\mathbf{t}=\infty$ における引限界ひずみ $\varepsilon_{\infty}$ は, $100 \times 10^{-6}$ 前後で ほぼ一定值となり，直接引張り試験により求められた硬化体の値 8), 9) と同程度の值となった。

以上より式(1), 式(2)，および式(3)中の係数 $\mathbf{t a}, \mathbf{a}_{0}, \mathbf{a}_{1}, \mathbf{a}_{2}$ は外気温度の影響を受けることを示し，その算定式を定めること ができた。

図 $6(\mathrm{a}) \sim(\mathrm{e})$, 各外気温度における引張り限界ひずみの実験 結果および以上に述へたた解析結果を示す。両式は実験値の傾向と よく対応しており, 引張り限界ひずみが極小となる時期, 值とも に良い精度で表現できている。このことから初期脆性は, 前述の, 粘性体としての性質が卓越してコンクリートが大きな流動性並び に変形能力を有している領域 I，および弾性体としての性質が卓 越する領域IIの両者がオーバーラップする領域において, 粘性体 としての変形能力の急速な低下および弾性体としての変形能力の 発現が相互に影響することにより生じる現象であると説明するこ とができた。

ここで，式中の定数 $\mathrm{T}$ 。は，先の基準温度に相当するものである と考えられるが，tq や a o どの算定式によって值が若干異なって

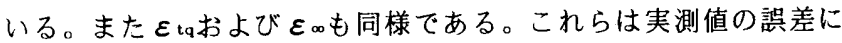
影響を受けたものと考えられるが，算定式の使用に際しては一定 値を用いることができれば赛用上も望ましい。これらも考慮して， 式(1), 式(2), および式(3)を外気温度 $\mathrm{T}$ の関数として再度記述す ると，それそれ式(8)，および式(9)となる。

$$
\begin{aligned}
& \varepsilon_{\mathrm{cr}(t)}=\varepsilon_{\mathrm{tq}}-\mathbf{a}_{0}\left(\mathbf{t}-\mathbf{t}_{\mathrm{q}}\right) \\
& =\varepsilon_{\mathrm{tq}_{\mathrm{q}}}-\mathbf{a}_{00}\left(\mathrm{~T}-\mathrm{T}_{0}\right)\left(\mathbf{t}-\mathbf{t}_{0} /\left(\mathrm{T}-\mathrm{T}_{0}\right)^{3 / 2}\right), \\
& (0 \leqq t \leqq t q, 15 \leqq T \leqq 35) \\
& \begin{aligned}
\varepsilon_{\mathrm{cr}}(\mathbf{t})= & \varepsilon_{\mathrm{tq}} \exp \left(-\mathbf{a}_{1}\left(\mathbf{t}-\mathbf{t q}_{\mathrm{q}}\right)\right)+\varepsilon_{\infty}\left(\mathbf{1}-\exp \left(-\mathbf{a}_{2}\left(\mathbf{t}-\mathbf{t q}_{\mathrm{q}}\right)\right)\right) \\
= & \varepsilon_{\mathrm{tq}} \exp \left(-\mathbf{a}_{10}\left(\mathrm{~T}-\mathrm{T}_{0}\right)\left(\mathbf{t}-\mathbf{t}_{0} /\left(\mathrm{T}-\mathrm{T}_{0}\right)^{3 / 2}\right)\right) \\
& +\varepsilon_{\infty}\left(1-\exp \left(-\mathbf{a}_{20} /\left(\mathrm{T}-\mathrm{T}_{0}\right)\left(\mathbf{t}-\mathrm{t}_{0} /\left(\mathrm{T}-\mathrm{T}_{0}\right)^{3 / 2}\right)\right)\right), \\
& \left(\mathbf{t}_{\mathrm{q}} \leqq \mathbf{t} \leqq 24,15 \leqq \mathrm{~T} \leqq 35\right)
\end{aligned}
\end{aligned}
$$



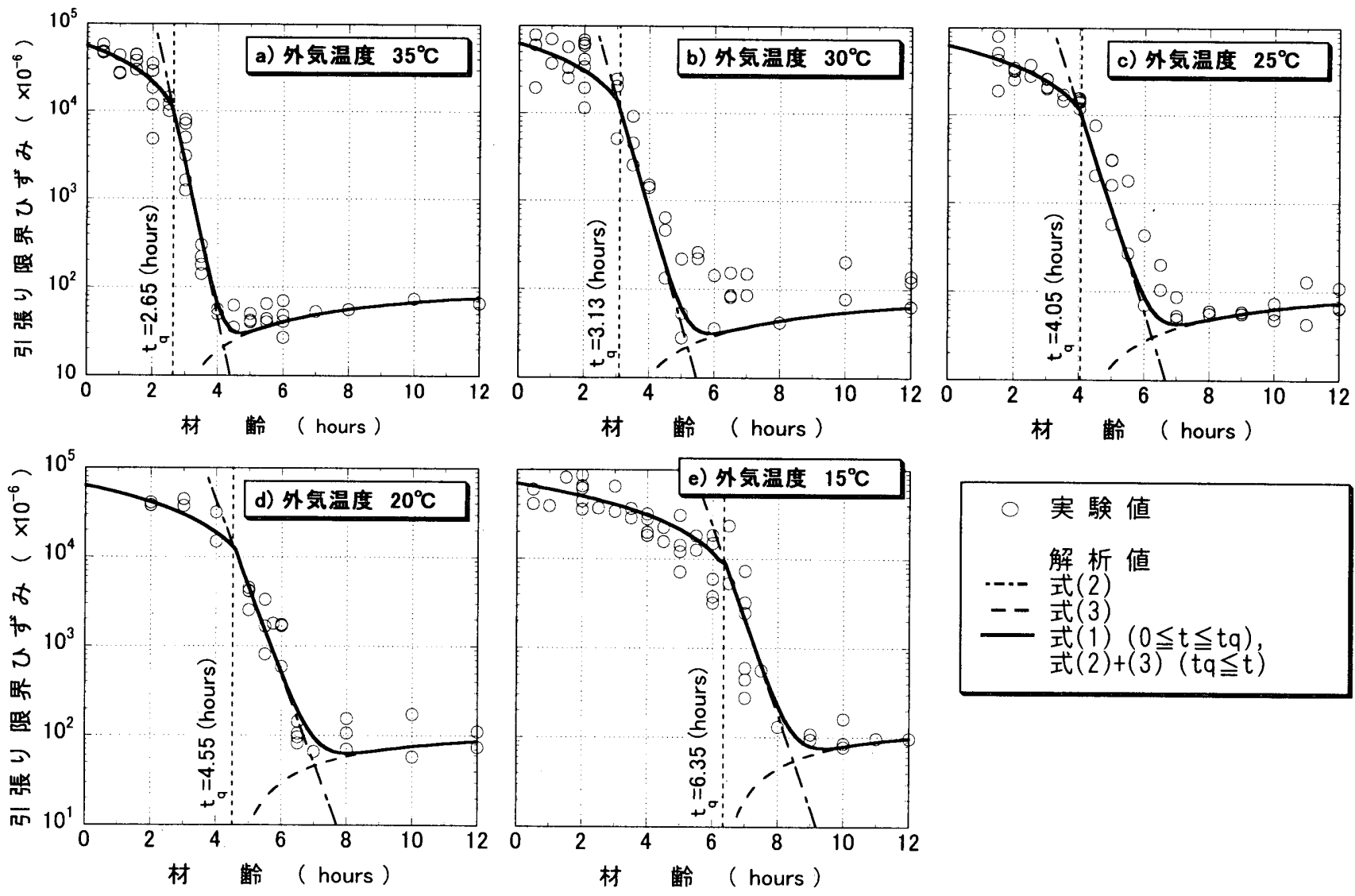

因6 引張り限界ひずみの実験値と解析値

ここに

$\varepsilon_{\mathrm{cr}}(\mathbf{t}):$ 引張り限界ひずみ $\left(\times 10^{-6}\right)$

t : 材齢 (hours)

tq : 領域 II 開始材齢 (hours), $=\mathbf{t}_{0} /\left(\mathrm{T}-\mathrm{T}_{0}\right)^{3 / 2}$

$\mathrm{T}$ : 外気温度 $\left({ }^{\circ} \mathrm{C}\right)$

$\mathrm{T}$ 。：基準温度 $\left(=-10^{\circ} \mathrm{C}\right)$

$\varepsilon_{\mathrm{tq}} \quad ：$ 材齢 $\mathbf{t}=\mathbf{t} \mathbf{q}$ における引張り限界ひずみ $\left(=10,000 \times 10^{-6}\right)$

$\varepsilon_{\infty} \quad:$ 材㯝 $\mathbf{t}=\infty$ における引張り限界ひずみ, $\left(=100 \times 10^{-6}\right)$

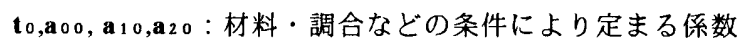

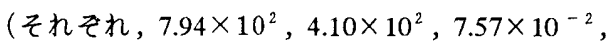
5.41)

上式を用いて外気温度 $\mathrm{T}$ を入力条件とした解析結果を図 7 に示 す。図中の・印は，上記式(9)を微分して得られる式(10)，および これを式(9)に代入して得られる式(11)より算定される引張り限界 ひずみの各外気温度での極小値を示している。破線は式(10)を横 軸, 式(11)を縦軸にとることによる引張り限界ひずみ極小值の軌 跡を表している。

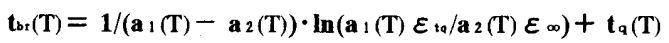

式(10)
$\varepsilon_{\mathrm{br}(\mathbf{T})}=\varepsilon_{\mathrm{cr}\left(\mathbf{t b r}_{\mathrm{r}}(\mathbf{T})\right)}$

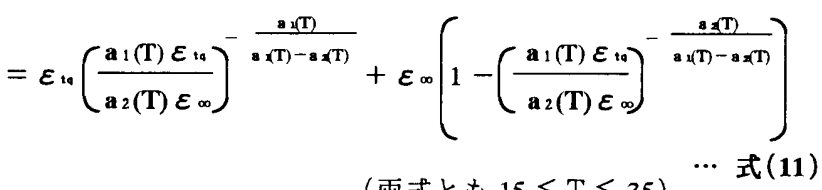

（両式とも $15 \leqq T \leqq 35 ）$

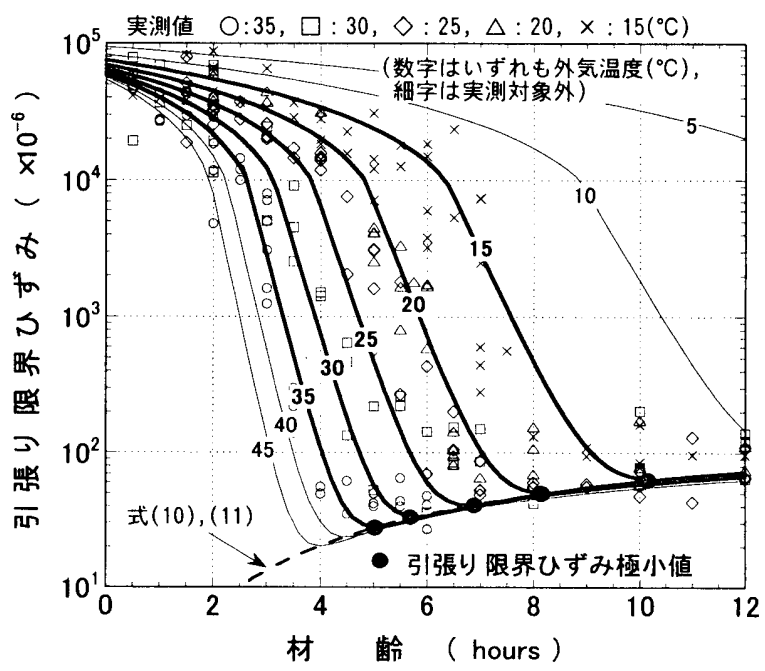

図 7 引張り限界ひずみの極小値と外気温度の関係 
ここに

$\operatorname{tor}(\mathbf{T})$ : 外気温度 $\mathbf{T}\left({ }^{\circ} \mathrm{C}\right)$ において引張り限界ひずみが 極小值を示す材齢 (hours)

$\varepsilon_{\mathrm{br}}(\mathbf{T})$ ：外気温度 $\mathbf{T}\left({ }^{\circ} \mathrm{C}\right)$ における引張り限界ひずみの 極小値 $\left(\times 10^{-6}\right)$

同図より，コンクリートが初期脆性を示す時期が，温度が高い ほど早くなること，またそのときの引張り限界ひずみの極小值が 温度が高いほど低くなる現象が，上に示した式(8)〜式(11)から定 量的に表現できることが明らかである。またこれらの式を用いる ことにより, 外気温度 $15 \sim 35^{\circ} \mathrm{C}$ の範囲における任意の温度条件 下において引張り限界ひずみが極小値を示す時期および值を定量 的に表すことができる。

\section{5. まとめ}

本研究では，種々の外気温度条件下における引張り限界ひずみ の経時変化を詳細に測定し，これを温度の関数として定式化を行 つた。得られた結果を以下に示す。

(1)引張り限界ひずみが若齢時に極小值を示すいわゆる初期脆性は, 粘性体としての性質が卓越してコンクリートが大きな流動性並 びに変形能力を有している領域 I，および弾性体としての性質 が卓越する領域IIの雨者がオーバーラッブする領域において， 粘性体としての変形能力の急速な低下および弾性体としての変 形能力の発現が相互に影響することにより生じる現象であるこ とを定量的に説明できた。

(2)それそれの領域において引張り限界ひずみの関係式を提案し, 実験值との比較を行った結果，解析值は実際の傾向を非常によ く表すことが明らかとなった。また各式の定数も温度の関数と して表現できることを明らかにした。本解析式を用いて，引張 り限界ひずみが極小值を示す時期および值を定量的に表すこと
ができる。

(3)本解析式を用いて，コンクリートが初期脆性を示す時期が温度 が高いほど早くなること，またそのときの引張り限界ひずみの 極小值が温度が高いほど低くなる現象が，定量的に表現できる ことが示された。

謝辞 本実験および解析の遂行にあたり，本学大学院生東川大， 杉田均両君の多大な協力を得た。末尾ながらここに謝意を表す。

\section{参考文献}

1）松藤泰典，小山智幸：セメントモルタルの硬化初期における引張り限界 ひずみの経時変化，コンクリート工学年次論文報告集，Vol.16，No.1， pp.681 686, 1994.6

2）松藤泰典：暑中コンクリート体系序説 II．暑中コンクリート各論, セメント・コンクリート，No.572, pp.36〜 42, 1994.10

3）小山智幸: 暑中環境下で打設されるコンクリートの温度ひび割れ防止 に関する研究，平成 7 年度科学研究費補助金 (一般研究 (c)), 研究課題 番号 $06650636,1996.3$

4）シリカフュームを用いたコンクリートの調合設計・施エガイドライン, 日本建築学会, pp.122 125, 1996

5）笠井芳夫：コンクリートの初期引張強度に関する研究，コンクリート・ ジャーナル, Vol.7, No.7, pp.1〜 10, 1969.2

6）笠井芳夫：コンクリートの㠜結・硬化に関する一考察，セメント技術年 報XXIII, pp.214 218, 1969

7）コンクリート便覧，技報堂，p.216，pp.403〜 404, 1996

8）吉本彰, 長谷川博, 川上正史 : コンクリートおよびモル夕ルの純引張, 圧裂および曲げ強度の比較，セメント・コンクリート，No.435, pp.42 $\sim 48,1983.5$

9）渡辺夏也，橋場光雄，コンクリートの引張強度に関する研究，セメント 技術年報 38, pp. $294 \sim 297,1984$ 